\title{
Differential involvement of estrogen receptor $\alpha$ and estrogen receptor $\beta$ in the healing promoting effect of estrogen in human keratinocytes
}

\author{
Sara Merlo ${ }^{1,2}$, Giuseppina Frasca ${ }^{1}$, Pier Luigi Canonico ${ }^{2}$ and Maria Angela Sortino ${ }^{\mathbf{1}}$ \\ ${ }^{1}$ Department of Experimental and Clinical Pharmacology, University of Catania, Viale Andrea Doria 6, 95125 Catania, Italy \\ ${ }^{2}$ DISCAFF, University of Piemonte Orientale, 28100 Novara, Italy \\ (Correspondence should be addressed to M Angela Sortino; Email: msortino@unict.it)
}

\begin{abstract}
Estrogen affects proliferation and migration of different skin components, thus influencing wound healing processes. The human keratinocyte cell line NCTC 2544 has been used to examine the effects of estrogen, dissect its mechanism of action and characterize receptor subtypes involved. Western blot and immunocytochemical analyses confirmed the expression of estrogen receptors (ERs) $\alpha$ and $\beta$, with prevalence in the nuclear and extranuclear compartment, for $E R \alpha$ and $E R \beta$ respectively. Treatment with $10 \mathrm{nM} 17 \beta$ estradiol $\left(17 \beta-E_{2}\right)$ and the ER $\alpha$ and ER $\beta$ selective agonists, 1,3,5-tris(4-hydroxyphenyl)-4-propyl-1H-pyrazole (PPT; $100 \mathrm{nM}$ ), and diarylpropionitrile (DPN; $1 \mathrm{nM}$ ) produced a slight but significant increase in cell proliferation, as by 3-(4,5dimethylthiazol-2-yl)-2,5-diphenyltetrazolium bromide and bromodeoxyuridine incorporation assays, only after a longterm treatment $(96 \mathrm{~h})$. Analysis of cell migration by a scratch wound assay showed that $17 \beta-\mathrm{E}_{2}(10 \mathrm{nM})$ accelerated
\end{abstract}

migration between 5 and $24 \mathrm{~h}$ after scratching, an effect confirmed by the transwell migration assay. PPT and DPN elicited similar effects. Pre-treatment with the mitogenactivated protein kinase inhibitor, U0126 $(1 \mu \mathrm{M})$, abolished the ability of $17 \beta-\mathrm{E}_{2}$ and DPN, but not of PPT, to accelerate wound closure. TGF- $\beta 1(10 \mathrm{ng} / \mathrm{ml})$ produced a similar positive effect on wound closure and the TGF- $\beta 1$ receptor antagonist, SB431542 $(10 \mu \mathrm{M})$, reduced the ability of $17 \beta-\mathrm{E}_{2}$ and PPT to accelerate cell migration, but did not modify DPN effect. It is suggested that estrogen positively affects in vitro wound healing by stimulating cell proliferation after long-term exposure but mainly by accelerating cell migration within a few hours from treatment. Selective activation of ER $\beta$ may result in favorable stimulation of wound healing without any increase of transforming growth factor- $\beta 1$ production.

Journal of Endocrinology (2009) 200, 189-197

\section{Introduction}

It is largely known that the regulatory roles of estrogen extend well beyond the reproductive system. In all tissues and cell types, estrogen exerts its actions by interacting with two specific receptor subtypes, $\alpha$ and $\beta$ (ERs). These are transcription factors, which dimerize following ligand binding, recruit a number of different co-regulators, and finally bind to target sequences on gene promoters. However, extremely rapid responses triggered by estrogen, not ascribable to the 'classical' genomic action, have also been described. They are likely linked to membrane events, coupled to intracellular second messengers that in turn activate kinase signaling cascades. Among these are the mitogen-activated protein kinase (MAPK), the phosphatidylinositol 3-kinase, the protein kinase $\mathrm{A}$, and protein kinase $\mathrm{C}$ pathways (Cheskis et al. 2007). The actual identity of putative membrane receptors has not been determined. While evidence points to a membrane localization of ER $\alpha$ and/or ER $\beta$, several studies on different cell types have suggested the existence of a specific membrane receptor (Verdier-Sevrain et al. 2006). Rapid signaling has been shown to impact genomic activity, resulting in the integration of membrane and nuclear actions of estrogen, thus granting plasticity to the cellular response to the hormone (Levin 2005).

Skin represents one of estrogen's targets outside the reproductive system. Different skin cell types are directly affected by the hormone in both physiological and pathological conditions (Thornton 2005). Particularly relevant is the ability of the hormonal environment to affect wound healing that is a complex, multi-stage process involving inflammatory response, angiogenesis, and extracellular membrane deposition and remodeling. In vivo studies have shown that healing is worsened in ovariectomized rats, but improves following estrogen administration (Ashcroft et al. 1997, 1999). Accordingly, hormone replacement therapy improved post-wounding epithelialization in postmenopausal women, restoring a healing rate similar to that of premenopausal women (Ashcroft et al. 1997). In addition, topical and systemic estrogen treatments ameliorated acute wound healing in the elderly of both sexes (Ashcroft et al. 1997, 1999). 
Estrogen impacts different stages of the healing process; $17 \beta$-estradiol $\left(17 \beta-\mathrm{E}_{2}\right)$ has been shown to have a proliferative effect on epidermal keratinocytes in aged human skin in vivo (Son et al. 2005) and on primary human keratinocytes in vitro, where it induces cyclin D2 and increases cell distribution in the $\mathrm{S}$ phase of cell cycle (Kanda \& Watanabe 2004a). 17 $\beta-\mathrm{E}_{2}$ has also been demonstrated to enhance the production of granulocyte-macrophage colony-stimulating factor, which is involved in improving wound repair ability (Kanda \& Watanabe 2004b).

Although the positive effects of estrogens on skin wound healing have been widely demonstrated both in vivo and in vitro, very little is known about the mechanisms underlying such action and the relative contribution of $\mathrm{ER} \alpha$ and $\mathrm{ER} \beta$. In the present study, we used the human keratinocyte cell line NCTC 2544 as an in vitro model to address these issues. We show that ER $\alpha$ and $E R \beta$ differentially affect keratinocyte cell migration and proliferation, key events during wound repair and that both membrane and genomic actions are involved in these effects.

\section{Materials and Methods}

\section{Cell culture and reagents}

NCTC 2544 human keratinocyte cells (Interlab Cell Line Collection, Genoa, Italy) were maintained at $5 \% \mathrm{CO}_{2}$ and $37^{\circ} \mathrm{C}$ in phenol red-free DMEM supplemented with $10 \%$ FCS and penicillin/streptomycin (all from Invitrogen). All experiments were carried out in phenol red-free and serumfree DMEM.

$17 \beta-\mathrm{E}_{2}$ (Sigma-Aldrich Co), 1,3,5-tris(4-hydroxyphenyl)4-propyl-1H-pyrazole, and diarylpropionitrile (PPT and DPN; Tocris Cookson Ltd, North Point, UK) were dissolved in ethanol; BSA-conjugated $17 \beta-\mathrm{E}_{2}$ (Sigma) was dissolved in 50\% ethanol; U0126 and SB431542 (Tocris Cookson) were dissolved in dimethyl sulfoxide (Sigma). Stock solutions were usually at a concentration of $10 \mathrm{mM}$. Subsequent dilutions for treatments were made in aqueous solution so that all controls received an amount of vehicle that was always less than $0 \cdot 01 \%$.

Transforming growth factor- $\beta 1$ (TGF- $\beta 1$; Peprotech, Rocky Hill, NJ, USA) was dissolved in an acidic $0 \cdot 1 \%$ BSA sterile solution.

\section{Western blot analysis}

NCTC 2544 cells were harvested in $10 \mathrm{mM}$ Tris lysis buffer containing $5 \mathrm{mM}$ EDTA, 1\% Triton X-100, and a proteaseand phosphatase-inhibitor cocktail mix (Sigma). Full lysis was obtained by sonication of the samples. Fractionation of nuclear and membrane/cytosolic protein extracts was carried out as described by Dai et al. (2007). Fifty micrograms of protein extract were separated by SDS-PAGE and transferred to nitrocellulose membranes (Hybond ECL, Amersham
Biosciences Europe $\mathrm{GmbH}$ ) using a Transblot semidry transfer cell. Membranes were then blocked in 3\% milk in PBS containing $0 \cdot 1 \%$ Tween-20, and processed for immunodetection with the following antibodies: rabbit anti-ER $\alpha$ (1:200), rabbit anti-ER $\beta$ (1:500), rabbit anti-TGF- $\beta 1$ (1:400; all from Santa Cruz Biotechnologies, Santa Cruz, CA, USA), rabbit anti-ERK and anti-phospho-ERK (1:1000, Cell Signaling Technology, Danvers, MA, USA), mouse antiactin (1:1000, Sigma), and HRP-conjugated secondary antibodies (all from Santa Cruz). Detection of specific bands was carried out using the Immobilon detection system (Millipore, Billerica, MA, USA).

\section{Immunocytochemistry}

NCTC 2544 cells were fixed in $4 \%$ paraformaldehyde, permeabilized with $0 \cdot 1 \%$ Triton X-100 when necessary, and saturated with $3 \%$ BSA. Cells were then incubated with mouse anti-ER $\alpha(1: 50)$ or rabbit anti $\operatorname{ER} \beta(1: 200)$ primary antibodies (both from Santa Cruz). For diaminobenzidine-based detection, cells were incubated for $2 \mathrm{~h}$ with biotinylated anti-mouse or anti-rabbit secondary antibodies followed by the $\mathrm{ABC}$ detection system (all from Vector Laboratories, Burlingame, CA, USA). For double-labeling experiments, FITC-conjugated anti-mouse (1:100, cat. n. AP192F, Chemicon, Temecula, CA, USA) and Texas Red-conjugated anti-rabbit (1:200, Santa Cruz) secondary antibodies were used.

\section{Analysis of the prediploid cell population}

Cells were collected and fixed in ice-cold $70 \%$ ethanol, treated for $1 \mathrm{~h}$ at $37^{\circ} \mathrm{C}$ with $100 \mu \mathrm{g} / \mathrm{ml}$ ribonuclease and incubated with $50 \mu \mathrm{g} / \mathrm{ml}$ propidium iodide (both from Sigma) just prior to analysis of DNA content and ploidy by flow cytometry, carried out with a Coulter-Elite Flow Cytometer.

\section{3-(4,5-Dimethylthiazol-2-yl)-2,5-diphenyltetrazolium bromide proliferation assay}

NCTC 2544 cell proliferation was evaluated by a colorimetric assay based on the conversion of 3-(4,5-dimethylthiazol-2-yl)-2,5-diphenyltetrazolium bromide (MTT) into blue formazan (absorbance $=560 \mathrm{~nm}$ ) by mitochondrial activity of viable cells. After incubation with the MTT substrate (Sigma) for $2 \mathrm{~h}$ at $37^{\circ} \mathrm{C}$, cells were disrupted for $30 \mathrm{~min}$ at $37^{\circ} \mathrm{C}$ with an isopropanol/acetic acid solution containing 1\% SDS, and absorbance was measured in a plate reader.

\section{Bromodeoxyuridine incorporation assay}

In parallel, NCTC 2544 cell proliferation was analyzed by evaluation of bromodeoxyuridine (BrdU) incorporation. Three micromolar BrdU (Sigma) was supplemented to the cells in the last $24 \mathrm{~h}$ of a 96-h treatment. Cells were fixed with $95 \% \mathrm{EtOH}$, subjected to acid treatment $(2 \mathrm{~N} \mathrm{HCl})$ for DNA 
denaturation, followed by neutralization with $0 \cdot 1 \mathrm{M}$ Trisborate and finally processed for immunostaining with mouse anti-BrdU (MAB3510, 1:2000, Chemicon) for $2 \mathrm{~h}$ and biotinylated anti-mouse (1:200, Vector) for $1 \mathrm{~h}$. Cells were stained with the $\mathrm{ABC}$ detection system (Vector) using diaminobenzidine (Sigma) as a substrate. Immunopositive cells were counted in three randomly selected fields/wells from at least six wells per experiment.

\section{Scratch wound migration assay}

Subconfluent monolayers of NCTC 2544 cells were scratched with a sterile P200 pipette tip. After removal of the resulting debris by repeated washes, cells were subjected to treatment and scratch wound closure was monitored by phase microscopy capturing images of the same field with a $10 \times$ objective at $0,5,10$, and $24 \mathrm{~h}$. The cell free area was determined with the aid of the image processing software 'Image J' developed by NIH and in the public domain.

\section{Transwell migration assay}

NCTC 2544 cells were plated in the upper chamber of $8 \mu \mathrm{m}$ pore size transwell insert (Corning, Lowell, MA, USA). Cells were immediately exposed to treatment and allowed to migrate for $24 \mathrm{~h}$ toward chemoattracting 10\% FCS-supplemented medium present in the lower chamber. Nonmigrating cells in the upper chamber were removed with the aid of a cotton swab, while migrated cells adhering to the lower surface of the membrane were stained with eosin and hematoxylin for cell counting (five randomly selected fields/transwell from at least three transwells per experiment).

(a)

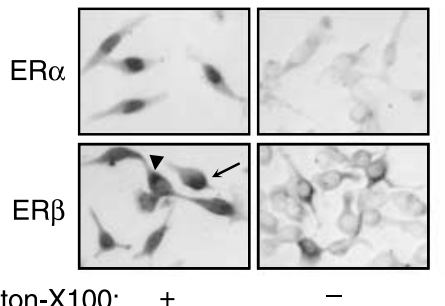

\section{Statistical analysis}

All experiments were repeated three to six times and were analyzed by one-way ANOVA followed by Newman-Keuls test for significance, as indicated in figure legends. Where appropriate, a two-way ANOVA followed by a Bonferroni test for significance was applied. $P<0.05$ was taken as the criterion for statistical significance.

\section{Results}

The expression of estrogen receptor subtypes $\alpha$ and $\beta$ in NCTC 2544 human keratinocytes was analyzed by immunocytochemical analysis. When cells were permeabilized with Triton X-100 (0-1\%), allowing antibodies to reach both the cytoplasm and the cell nucleus, the two receptors appeared to be located in different compartments. ER $\alpha$ showed very strong nuclear labeling, while ER $\beta$ was expressed at high levels in the extranuclear region, yet showing a remarkable staining also inside the nucleus (Fig. 1a). Double immunocytochemistry with both anti-ER $\alpha$ and anti-ER $\beta$ antibodies confirmed such complementary expression. Most cells showed in fact intense nuclear ER $\alpha$ staining (Fig. 1b) and a more diffuse ER $\beta$ immunopositivity involving both nuclear and membrane compartments (Fig. 1b). Omission of the permeabilization step, a previously reported method for analysis of expression of cell surface antigens (Verdier-Sevrain et al. 2004), supported the nuclear localization of $E R \alpha$, which was not anymore detectable, and the extranuclear expression of ER $\beta$, whose labeling was still evident (Fig. 1a). To further confirm these results, western blot analysis of nuclear or (b)

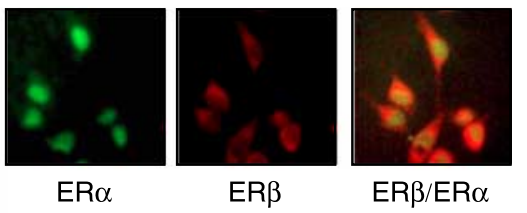

(c)

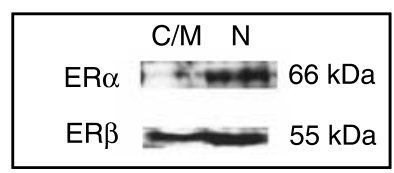

Figure 1 (a) Expression of $E R \alpha$ and $E R \beta$ in human NCTC 2544 keratinocytes. Immunocytochemical analysis of ER $\alpha$ and ER $\beta$ in the presence (a; left panels) or absence ( $\mathrm{a}$, right panels) of the permeabilization agent Triton X-100 $(0 \cdot 1 \%)$. Arrow and arrowhead indicate nuclear and extranuclear expression of $E R \beta$ respectively. On the right panels (b), double immunocytochemical analysis of $E R \alpha$ (green staining), ER $\beta$ (red staining) and co-localization of the two receptors in the nuclei (yellow staining after merge). (c) Western blot analysis of ERs expression in cytoplasm/membrane (C/M) and nuclear $(\mathrm{N})$ protein fraction. Full colour version of this figure available via http://dx.doi. org/10.1677/JOE-08-0050. 
cytosolic/membrane (C/M) fractions was carried out. Results showed that ER $\alpha$ was strongly enriched in nuclear fractions, while only a faint band was detectable in the $\mathrm{C} / \mathrm{M}$ compartment. By contrast, ER $\beta$ yielded a fairly intense band in both fractions (Fig. 1c).

$17 \beta-E_{2}$ effects on NCTC 2544 cell proliferation were examined. Cells were plated at a low density and treated with $10 \mathrm{nM} 17 \beta-\mathrm{E}_{2}$ in phenol red-free and serum-free medium for 24,48 , or $96 \mathrm{~h}$, and proliferation assessed by the MTT assay. At earlier time points, there was no significant effect on cell proliferation (not shown), but after $96 \mathrm{~h}$ of exposure to the hormone a small but significant induction of cell proliferation became evident (Fig. 2a). This effect was clearly mediated by ERs as shown by its prevention in the presence of $1 \mu \mathrm{M}$ of the ER antagonist ICI $182780(137 \pm 4 \cdot 3$ and $112+6 \cdot 2 \%$ of control in $17 \beta \mathrm{E}_{2^{-}}$and $17 \beta \mathrm{E}_{2} \pm$ ICI 182780 -treated conditions respectively). Interestingly, treatment with $100 \mathrm{nM}$ PPT and $1 \mathrm{nM} D \mathrm{DPN}$, selective agonists of ER $\alpha$ and $\operatorname{ER} \beta$ respectively, fully mimicked the effect of $17 \beta-\mathrm{E}_{2}$ (Fig. 2a). Pre-treatment with $1 \mu \mathrm{M}$ of the MAPK pathway antagonist U0126 for $30 \mathrm{~min}$, prevented the stimulatory effect on keratinocyte proliferation induced by exposure for $96 \mathrm{~h}$ to
$17 \beta-\mathrm{E}_{2}$ or the selective ER $\beta$ agonist, DPN for $96 \mathrm{~h}$, but had only a partial, not significant effect, against $100 \mathrm{nM}$ PPT (Fig. 2b). To rule out the possibility that the observed effects were due to an increased viability of cells during treatment rather than increased proliferation, BrdU uptake assay was performed. Cells were treated with $10 \mathrm{nM} 17 \beta-\mathrm{E}_{2}, 100 \mathrm{nM}$ PPT, and $1 \mathrm{nM} \mathrm{DPN}$ for $96 \mathrm{~h}$, and exposed to $3 \mu \mathrm{M}$ of the nucleotide analog BrdU during the last $24 \mathrm{~h}$ of treatment. Immunocytochemical analysis followed by cell count showed that $17 \beta-E_{2}, P P T$, and DPN, all significantly increased the number of cells that had incorporated BrdU compared with control (Fig. 2c). No significant effect was observed after shorter time incubation with the ER agonists (data not shown). In addition, cytofluorometric analysis of the prediploid, apoptotic population by propidium iodide staining was carried out, showing that the percentage of cell death was negligible (data not shown).

The ability of $17 \beta-E_{2}$ and of the $\operatorname{ER} \alpha$ and $\operatorname{ER} \beta$ agonists, PPT and DPN, to modify the migration rate of NCTC 2544 cells was tested by the scratch wound closure assay. After scratching a subconfluent monolayer of cells with a P200 pipette tip and completely removing resulting debris by (a)

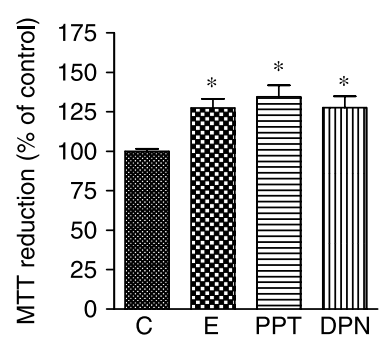

(b)

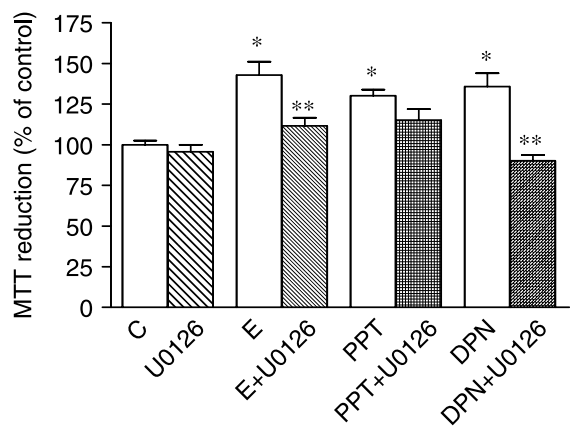

(c)

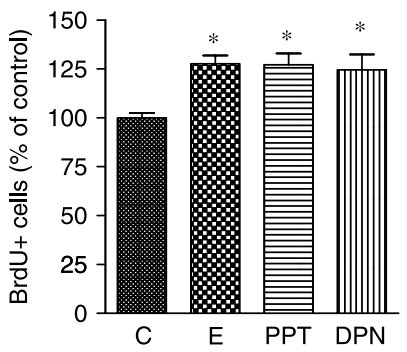

Figure 2 Effect of $17 \beta-E_{2}$ and selective ER agonists on NCTC 2544 cell proliferation. (a) Cells were treated with $17 \beta-E_{2}(E ; 10 \mathrm{nM})$, the selective $E R \alpha$ agonist PPT $(100 \mathrm{nM})$ or the selective ER $\beta$ agonist DPN $(1 \mathrm{nM})$ for $96-\mathrm{h}$ prior to incubation with tetrazolium salts and evaluation of cell proliferation by the MTT reduction assay. In b, cells were pre-treated with $1 \mu \mathrm{M} \cup 0126$ for 30 min prior to addition of $17 \beta-E_{2}$, PPT or DPN for $96 \mathrm{~h}$ and proliferation analysis by the MTT assay. In data reported in c, $3 \mu \mathrm{M} \mathrm{BrdU}$ was added during the last $24 \mathrm{~h}$ of a $96-\mathrm{h}$ incubation. Cells were then processed for immunocytochemical analysis and counted. Data are mean \pm s.E.M. of five to six independent experiments each run in quadruplicates. ${ }^{*} P<0 \cdot 05$ versus control and $* * P<0.05$ vs $17 \beta-E_{2}$ and DPN alone by one-way ANOVA followed by Newman-Keuls post hoc test for significance. 
(a)
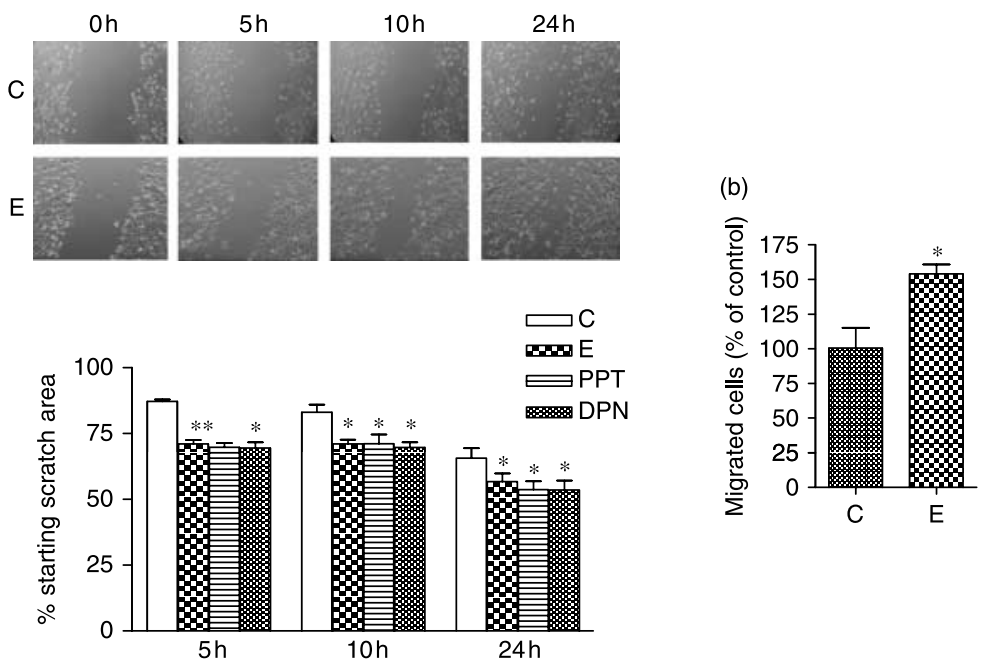

Figure 3 Time-course analysis of the effect of $17 \beta-E_{2}$ and selective ER agonists on NCTC 2544 cell migration. Subconfluent cell monolayers were scratched with a P200 pipette tip and treated with $17 \beta-\mathrm{E}_{2}(\mathrm{E} ; 10 \mathrm{nM})$, PPT $(100 \mathrm{nM})$, or DPN $(1 \mathrm{nM})$. Migration rates were determined by measuring the free area outlined by the edge of the migratory front at $0,5,10$, and $24 \mathrm{~h}$ after scratching (a). Representative images from vehicle- and $17 \beta$ $\mathrm{E}_{2}$-treated cultures at different time points are shown in $\mathrm{a}$. In $\mathrm{b}$, the percentage of cells migrated through the $8 \mu \mathrm{m}$ pore size membrane of a transwell insert is reported $(* P<0.05$ versus control by Student's $t$-test). Bars represent mean \pm S.E.M. of five to eight independent experiments each run in triplicates. ${ }^{*} P<0 \cdot 05$ versus control by two-way ANOVA followed by Bonferroni post hoc test for significance.

repeated washing, cells were treated with either $10 \mathrm{nM} 17 \beta-$ $\mathrm{E}_{2}, 100 \mathrm{nM}$ PPT or $1 \mathrm{nM}$ DPN in phenol red-free and serum-free medium. Images of the same field were captured at time 0 and after 5,10 , and $24 \mathrm{~h}$, allowing monitoring of cell migration into the scratched area. Analysis at earlier time points did not allow detection of any change in migration rate in control and ER agonist-treated cells versus time 0. As shown in Fig. 3a, $17 \beta-\mathrm{E}_{2}(\mathrm{E})$, PPT, and DPN were able to significantly and comparably accelerate cell migration towards the free area. This effect was significant already at $5 \mathrm{~h}$ after scratching and was maintained at all time points examined, up to $24 \mathrm{~h}$ (Fig. 3a). Similar results were obtained when migration was analyzed in NCTC 2544 keratinocytes plated on a laminin-coated substrate (data not shown).

In parallel, cell migration was evaluated by the transwell migration assay, which confirmed the ability of $10 \mathrm{nM} 17 \beta-$ $\mathrm{E}_{2}$ to increase cell migration, as shown by the greater number of cells migrated toward a serum-rich medium used as chemoattractant (Fig. 3b).

Due to the early appearance of the observed effect on keratinocyte migration, the involvement of rapid, nongenomic pathways of estrogen action was hypothesized. Accordingly, $17 \beta-\mathrm{E}_{2}, \mathrm{PPT}$, and DPN all comparably increased the levels of phospho-ERK protein after a $15 \mathrm{~min}$ pulse, as shown by western blot analysis (Fig. 4a). However, blockade of the mitogen activated protein kinase (MAPK) pathway by pre-treatment of cells for $30 \mathrm{~min}$ with $1 \mu \mathrm{M}$ U0126, prevented the acceleration of cell migration induced by a $24-\mathrm{h}$ treatment with $17 \beta-\mathrm{E}_{2}$ and DPN, but did not modify the effect induced by PPT (Fig. $4 \mathrm{~b}$ ). Consistent with the involvement of a rapid membrane-activated pathway, treatment for $24 \mathrm{~h}$ with $100 \mathrm{nM}$ of the membrane impermeable BSA-conjugated $17 \beta-\mathrm{E}_{2}$ (E-BSA), that is able to trigger only rapid, membrane-related events, mimicked $17 \beta-\mathrm{E}_{2}$ effect, producing a significant acceleration of wound healing, sensitive to U0126 pre-treatment (Fig. 4c).

In an attempt to identify a mediator of the observed effects of estrogen on NCTC 2544 keratinocytes, TGF- $\beta 1$ was tested as a likely candidate. In contrast to what was expected, the stimulatory effect of $17 \beta-\mathrm{E}_{2}$ on NCTC2544 cell proliferation did not involve TGF- $\beta 1$ as it was not modified by pre-treatment of cells with the TGF- $\beta 1$ antagonist SB431542 (Fig. 5a).

TGF- $\beta 1$ was instead likely involved in keratinocyte migration as treatment of a scratched monolayer of NCTC 2544 cells with $10 \mathrm{ng} / \mathrm{ml}$ rhTGF- $\beta 1$ for $24-\mathrm{h}$ mimicked $17 \beta-$ $\mathrm{E}_{2}$ action by significantly increasing the rate of cell migration (Fig. 5b). More importantly, pre-treatment of the cells with $10 \mu \mathrm{M}$ of the TGF- $\beta 1$ receptor antagonist SB431542 for $30 \mathrm{~min}$, prevented the stimulatory effect on cell migration induced by subsequent exposure to $17 \beta-\mathrm{E}_{2}$ for $24 \mathrm{~h}$ (Fig. $5 \mathrm{c}$ ). However, treatment with the TGF- $\beta 1$ receptor antagonist SB431542 (10 $\mu \mathrm{M}$ for $30 \mathrm{~min})$ inhibited PPT-induced wound closure, but did not modify the effect induced by DPN (Fig. 5c). Accordingly, evaluation of NCTC 2544 cellular content of TGF- $\beta 1$ protein by western blot analysis 
(a)
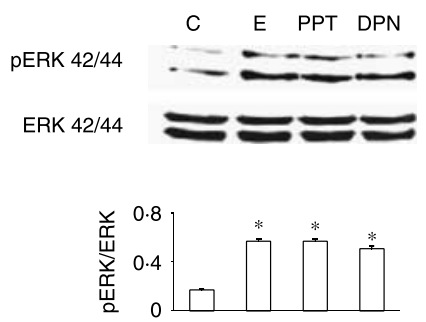

(b)

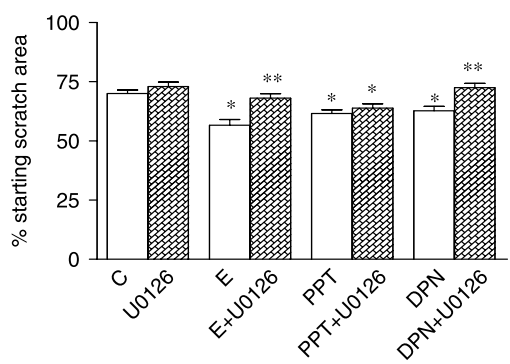

(c)

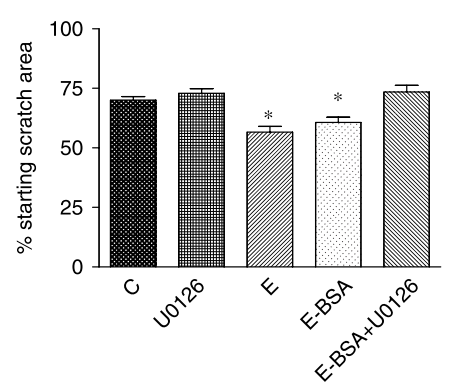

Figure 4 Involvement of MAPK pathway in estrogen-induced NCTC 2544 cell migration. (a) The effect of a 15 min pulse with $17 \beta-\mathrm{E}_{2}$ $(10 \mathrm{nM})$, PPT (100 $\mathrm{nM})$, or DPN (1 $\mathrm{nM})$ on phospho-ERK $1 / 2$, as by western blot analysis is shown. A representative immunoblot is shown; densitometric analyses, reported in the histogram, have been normalized over constitutive ERK $1 / 2$ expression and represent mean \pm S.E.M. of three independent experiments. In $b$, the effect of a pre-treatment of a scratched cell monolayer with $1 \mu \mathrm{M} \mathrm{U0126} \mathrm{for}$ $30 \mathrm{~min}$, prior to addition of $17 \beta-\mathrm{E}_{2}(\mathrm{E} ; 10 \mathrm{nM})$, PPT (100 nM), or DPN ( $1 \mathrm{nM}$ ) for $24 \mathrm{~h}$. Treatment of the scratched monolayer with $100 \mathrm{nM}$ membrane-impermeable BSA-conjugated $17 \beta-\mathrm{E}_{2}$ (E-BSA) for $24 \mathrm{~h}$ is reported in C. Bars represent mean \pm S.E.M. of three to five independent experiments each run in triplicates. ${ }^{*} P<0 \cdot 05$ versus respective controls by one-way ANOVA followed by NewmanKeuls post hoc test for significance. ${ }^{* *} P<0.05$ vs $17 \beta-\mathrm{E}_{2}$ and DPN alone by one-way ANOVA followed by Newman-Keuls post hoc test for significance.

revealed that TGF- $\beta 1$ levels were, unexpectedly, significantly increased by exposure for $24 \mathrm{~h}$ to $10 \mathrm{nM} 17 \beta-\mathrm{E}_{2}$ (E) and $100 \mathrm{nM}$ PPT, but were not modified by $1 \mathrm{nM} \mathrm{DPN}$, as shown by changes in a specific band at $25 \mathrm{kDa}$ (Fig. $5 \mathrm{~d}$ ). A visible proof of increased TGF- $\beta 1$ was provided by immunocytochemical analysis showing that cells treated for $24 \mathrm{~h}$ with
$10 \mathrm{nM} 17 \beta-\mathrm{E}_{2}$ (E) had a much stronger TGF- $\beta 1$ staining compared with vehicle-treated cultures (Fig. $5 \mathrm{~d}$ ).

\section{Discussion}

A role for estrogen in skin function, especially under conditions of cutaneous wound healing has long been analyzed (Gilliver et al. 2007). This may appear particularly relevant with aging when skin undergoes significant structural and functional changes, such as decrease in proliferative and migratory properties of cells, flattening of the dermoepidermal junction and disorganization of microcirculation. As a whole, these events lead to thinning, wrinkling and impairment of the re-epithelialization ability after a lesion (Ashcroft et al. 2002). In addition, the reduced levels of circulating estrogens in postmenopausal women have been related to an exacerbation of the detrimental effects of aging on skin. Estrogen are known to affect wound healing by influencing different skin cellular components, including fibroblasts, vascular endothelial cells, and keratinocytes as well as infiltrating inflammatory cells (Gilliver et al. 2007).

Keratinocytes play a key role in wound healing and our results show that estrogen affects not only proliferation but also migration of human keratinocytes. These effects seem to occur independently, they both involve $\operatorname{ER} \alpha$ and $\operatorname{ER} \beta$, but differential mechanisms in modifying proliferation and migration for the two receptor subtypes are suggested.

The expression of $E R \alpha$ and $E R \beta$ in human keratinocytes has been previously demonstrated although some controversies have emerged (Kanda \& Watanabe 2003, Thornton et al. 2003, Verdier-Sevrain et al. 2004) and a role for cell surface GPR 30 in mediating estrogen effects on keratinocytes has also been suggested (Kanda \& Watanabe 2004a). We now confirm that $\mathrm{ER} \alpha$ is expressed in human keratinocytes and that its expression predominates in the nuclear compartment, whereas ER $\beta$ is equally present in the nuclear as well as in the non-nuclear fraction. Both receptor subtypes contribute to a stimulatory action on keratinocyte proliferation, an effect that, as already shown (Urano et al. 1995), appears only after a long-term exposure to $17 \beta-\mathrm{E}_{2}$ (Kanda \& Watanabe 2004a, Verdier-Sevrain et al. 2004) or to the selective ER $\alpha$ and ER $\beta$ agonists, PPT, and DPN. This is also consistent with the recent report on the involvement of both $\operatorname{ER} \alpha$ and $\operatorname{ER} \beta$ in the positive effect of estradiol in keratinocytes following trauma-hemorrage (Moeinpour et al. 2008). While the effect of $17 \beta-\mathrm{E}_{2}$ and DPN was prevented by pre-treatment with the MAPK inhibitor U0126, under the same conditions, the stimulatory action of PPT was only reduced, suggesting that at least part of the stimulatory effect of estrogen on keratinocyte proliferation involves ER $\beta$ that is expressed on the cell membrane and is responsible for rapid, non-genomic signaling. In addition, activation of keratinocyte proliferation by $17 \beta-E_{2}$ does not imply increase in TGF- $\beta 1$ as it was not modified by treatment with the TGF- $\beta 1$ receptor antagonist SB431542. 
(a)

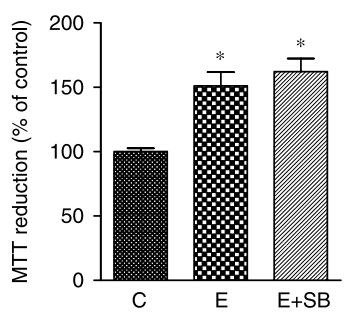

(c)

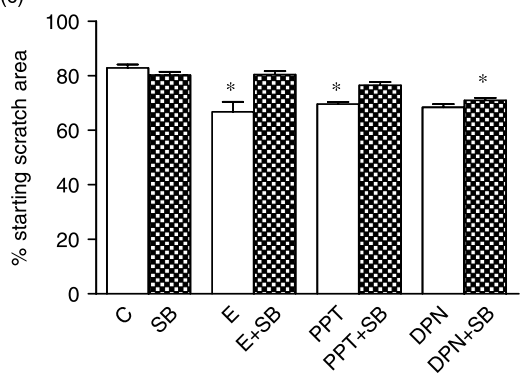

(b)

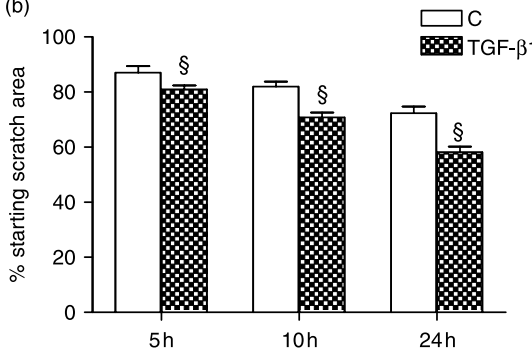

(d)

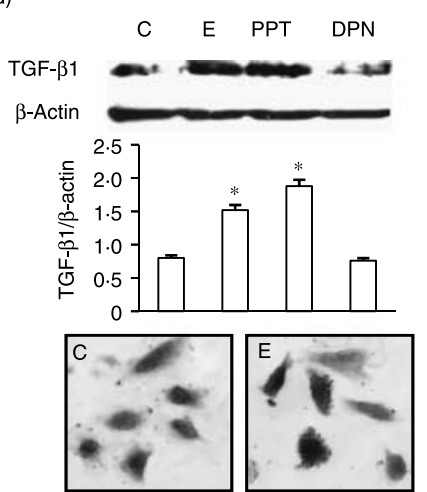

Figure 5 Involvement of TGF- $\beta 1$ in estrogen effects on NCTC 2544 cell proliferation and migration. The lack of effect of TGF- $\beta 1$ receptor blockade with SB431542 (SB; $10 \mu \mathrm{M})$ on NCTC 2544 cell proliferation (measured by MTT reduction) is shown in d. A scratched cell monolayer was treated with $10 \mathrm{ng} / \mathrm{ml} \mathrm{hrTGF-} \beta 1$ and cell migration was assessed at 5, 10, and $24 \mathrm{~h}$ as described in Materials and Methods section (b). In c the effect of a 30 min pre-treatment with $10 \mu \mathrm{M}$ SB431542 prior to addition of $17 \beta-E_{2}(E ; 10 \mathrm{nM})$, PPT (100 nM), or DPN (1 nM) for $24 \mathrm{~h}$, in a scratch wound assay is shown. In $\mathrm{d}$ a representative immunoblot (top panel) and immunocytochemical analysis (bottom panel) of TGF- $\beta 1$ expression following treatment with $17 \beta-E_{2}(E), P P T$, and DPN; data in the accompanying histogram are normalized over $\beta$-actin expression and represent mean \pm S.E.M. of three independent determinations. Bars represent mean \pm s.E.M. of three to five independent experiments each run in triplicates. ${ }^{*} P<0 \cdot 05$ versus other groups by one-way ANOVA followed by Newman-Keuls post hoc test for significance. $\S P<0 \cdot 05$ versus respective control by two-way ANOVA followed by Bonferroni post hoc test for significance.

TGF- $\beta 1$ has a well-established regulatory role in wound healing influencing all stages of wound repair, mainly through induction of extracellular matrix deposition and down-regulation of matrix degradation (Son et al. 2005, Faler et al. 2006, Lamar et al. 2008). In aged skin, topical application as well as systemic administration of TGF- $\beta 1$ affects tissue repair rates (Beck et al. 1993), accelerating wound closure and restoring normal healing (Pierce et al. 1989, Son et al. 2005). Estrogen positive effects on skin repair have been linked to TGF- $\beta 1$, although a direct correlation has been reported in dermal fibroblasts (Ashcroft et al. 1997) but no evidence exists, to date, in keratinocytes. In our experiments, however, that TGF- $\beta 1$ per se, was able to accelerate wound closure, seemed to play a role in the reparative effects of estrogen being involved in $17 \beta-\mathrm{E}_{2}$ property to stimulate keratinocyte migration. This effect was in fact prevented by the TGF- $\beta 1$ receptor antagonist SB431542. Interestingly, enough, a different role for ER $\alpha$ and $\operatorname{ER} \beta$ emerged, as revealed by the distinct behavior of the $\operatorname{ER} \alpha$ and $\operatorname{ER} \beta$ selective agonists. Thus, in contrast to $\operatorname{ER} \alpha$, ER $\beta$ seems to mediate estrogen's effect on keratinocyte migration independently of TGF- $\beta 1$, as the effect of the selective ER $\beta$ agonist DPN was not modified by pretreatment with SB431542 and DPN was not able to mimic $17 \beta-\mathrm{E}_{2}$ in inducing TGF- $\beta 1$ expression. This suggests that selective stimulation of ER $\beta$ may result in enhanced keratinocyte proliferation and migration without any increase in the production of TGF- $\beta 1$. Such an effect may be particularly beneficial, bearing in mind the favorable outcomes that a limited production of TGF- $\beta 1$ may have on the quality of scarring that follows wound repair (Ashcroft et al. 1997, Philipp et al. 2004, Riedel et al. 2007). In support of the possibility to target selectively ER $\beta$ is the preferential cell surface localization of this receptor subtype that is predominantly expressed in the membrane compartment and whose activation generates rapid, non-genomic signaling. 
Accordingly, treatment with the MAP kinase inhibitor U0126 prevented the ability of the ER $\beta$ selective agonist DPN to increase keratinocyte migration while not modifying the effect induced by the $\mathrm{ER} \alpha$ agonist, PPT. Furthermore, the effect of $17 \beta-\mathrm{E}_{2}$ on keratinocyte migration was fully mimicked by E2-BSA, a non-cell permeable estrogen agonist. All these data point to cell surface ER $\beta$ as a potential selective target to stimulate keratinocyte migration and proliferation thus contributing to wound healing.

Although preferentially mediating genomic actions, we cannot exclude that ER $\alpha$ is also expressed on the cell surface of keratinocytes, as from our results on assessment of receptor expression (immunocytochemistry and western blot), and activation of rapid, membrane-generated signaling (phosphoERK induction). However, the possibility exists that activation of $E R \beta$ is sufficient to obtain the stimulatory effect on wound repair through a mechanism that is unknown at present, but may be advantageous as it does not involve excessive production of TGF- $\beta 1$. Several other factors are known to be involved in wound healing, among which granulocyte/macrophage colony stimulating factor (GMCSF) that is produced by epidermal keratinocytes may play a central role (Mann et al. 2006, Fang et al. 2007). Specifically, GMCSF that is increased in response to estrogen stimulation of a membrane receptor (Mann et al. 2001, Kanda \& Watanabe $2004 b$ ) promotes migration of keratinocytes and endothelial cells (Mann et al. 2001).

In summary, the present data indicate a common function for $\operatorname{ER} \alpha$ and $\operatorname{ER} \beta$ in mediating changes in keratinocyte proliferation and migration. However, a unique role for ER $\beta$ that does not involve enhanced production of TGF- $\beta 1$ has been highlighted, opening a promising field for the development of ligands selective for a membrane-localized ER $\beta$. This may appear particularly valuable in view of the increasing interest toward innovative and alternative approaches, including TGF- $\beta 1$ targeting, for regenerative wound healing (Rhett et al. 2008).

\section{Declaration of interest}

We declare that there is no conflict of interest that could be perceived as prejudicing the impartiality of the research reported.

\section{Funding}

This work was in part supported by PAR 05-06 to MAS.

\section{References}

Ashcroft GS, Dodsworth J, van Boxtel E, Tarnuzzer RW, Horan MA, Schultz GS \& Ferguson MW 1997 Estrogen accelerates cutaneous wound healing associated with an increase in TGF-beta1 levels. Nature Medicine 3 1209-1215.
Ashcroft GS, Greenwell-Wild T, Horan MA, Wahl SM \& Ferguson MW 1999 Topical estrogen accelerates cutaneous wound healing in aged humans associated with an altered inflammatory response. American Journal of Pathology 155 1137-1146.

Ashcroft GS, Mills SJ \& Ashworth JJ 2002 Ageing and wound healing. Biogerontology 3 337-345.

Beck LS, DeGuzman L, Lee WP, Xu Y, Siegel MW \& Amento EP 1993 One systemic administration of transforming growth factor-beta 1 reverses ageor glucocorticoid-impaired wound healing. Journal of Clinical Investigation 92 2841-2849.

Cheskis BJ, Greger JG, Nagpal S \& Freedman LP 2007 Signaling by estrogens. Journal of Cellular Physiology 213 610-617.

Dai Y, Wei Z, Sephton CF, Zhang D, Anderson DH \& Mousseau DD 2007 Haloperidol induces the nuclear translocation of phosphatidylinositol 3'kinase to disrupt Akt phosphorylation in PC12 cells. Journal of Psychiatry and Neuroscience 32 323-330.

Faler BJ, Macsata RA, Plummer D, Mishra L \& Sidawy AN 2006 Transforming growth factor-beta and wound healing. Perspectives in Vascular Surgery and Endovascular Therapy 18 55-62.

Fang Y, Gong SJ, Xu YH, Hambly BD \& Bao S 2007 Impaired cutaneous wound healing in granulocyte/macrophage colony-stimulating factor knockout mice. British Journal of Dermatology 157 458-465.

Gilliver SC, Ashworth JJ \& Ashcroft GS 2007 The hormonal regulation of cutaneous wound healing. Clinics in Dermatology 25 56-62.

Kanda N \& Watanabe S 2003 17ß-Estradiol inhibits MCP-1 production in human keratinocytes. Journal of Investigative Dermatology 120 1058-1066.

Kanda N \& Watanabe S 2004 a 17 $\beta$-Estradiol stimulates the growth of human keratinocytes by inducing cyclin D2 expression. Journal of Investigative Dermatology 123 319-328.

Kanda N \& Watanabe S $2004 b$ 17 $\beta$-Estradiol enhances the production of granulocyte-macrophage colony-stimulating factor in human keratinocytes. Journal of Investigative Dermatology 123 329-337.

Lamar JM, Iyer V \& DiPersio CM 2008 Integrin alpha3beta1 potentiates TGFbeta-mediated induction of MMP-9 in immortalized keratinocytes. Journal of Investigative Dermatology 128 575-586.

Levin ER 2005 Integration of the extranuclear and nuclear actions of estrogen. Molecular Endocrinology 19 1951-1959.

Mann A, Breuhahn K, Schirmacher P \& Blessing M 2001 Keratinocytederived granulocyte-macrophage colony stimulating factor accelerates wound healing: stimulation of keratinocyte proliferation, granulation tissue formation, and vascularization. Journal of Investigative Dermatology 117 1382-1390.

Mann A, Niekisch K, Schirmacher P \& Blessing M 2006 Granulocytemacrophage colony-stimulating factor is essential for normal wound healing. Journal of Investigative Dermatology. Symposium Proceedings 11 87-92.

Moeinpour F, Choudhry MA, Poli de Figueiredo LF, Bland KI \& Chaudry IH 2008 Estradiol's salutary effects on keratinocytes following traumahemorrhage are mediated by estrogen receptor (ER)-alpha and ER-beta. Molecular Medicine 14 689-696.

Philipp K, Riedel F, Sauerbier M, Hormann K \& Germann G 2004 Targeting TGF-beta in human keratinocytes and its potential role in wound healing. International Journal of Molecular Medicine 14 589-593.

Pierce GF, Mustoe TA, Lingelbach J, Masakowski VR, Griffin GL, Senior RM \& Deuel TF 1989 Platelet-derived growth factor and transforming growth factor-beta enhance tissue repair activities by unique mechanisms. Journal of Cell Biology 109 429-440.

Rhett JM, Ghatnekar GS, Palatinus JA, O'Quinn M, Yost MJ \& Gourdie RG 2008 Novel therapies for scar reduction and regenerative healing of skin wounds. Trends in Biotechnology 26 173-180.

Riedel K, Riedel F, Goessler UR, Germann G \& Sauerbier M 2007 Tgf-beta antisense therapy increases angiogenic potential in human keratinocytes in vitro. Archives of Medical Research 38 45-51.

Son ED, Lee JY, Lee S, Kim MS, Lee BG, Chang IS \& Chung JH 2005 Topical application of 17beta-estradiol increases extracellular matrix protein synthesis by stimulating tgf-Beta signaling in aged human skin in vivo. Journal of Investigative Dermatology 124 1149-1161.

Thornton MJ 2005 Oestrogen functions in skin and skin appendages. Expert Opinion on Therapeutic Targets 9 617-629. 
Thornton MJ, Taylor AH, Mulligan K, Al-Azzawi F, Lyon CC, O’Driscoll J \& Messenger AG 2003 Oestrogen receptor beta is the predominant oestrogen receptor in human scalp skin. Experimental Dermatology 12 181-190.

Urano R, Sakabe K, Seiki K \& Ohkido M 1995 Female sex hormone stimulates cultured human keratinocyte proliferation and its RNA- and protein-synthetic activities. Journal of Dermatological Science 9 176-184.

Verdier-Sevrain S, Yaar M, Cantatore J, Traish A \& Gilchrest BA 2004 Estradiol induces proliferation of keratinocytes via a receptor mediated mechanism. FASEB Journal 18 1252-1254.
Verdier-Sevrain S, Bonte F \& Gilchrest B 2006 Biology of estrogens in skin: implications for skin aging. Experimental Dermatology 15 83-94.

Received in final form 6 November 2008

Accepted 8 November 2008

Made available online as an Accepted Preprint 13 November 2008 